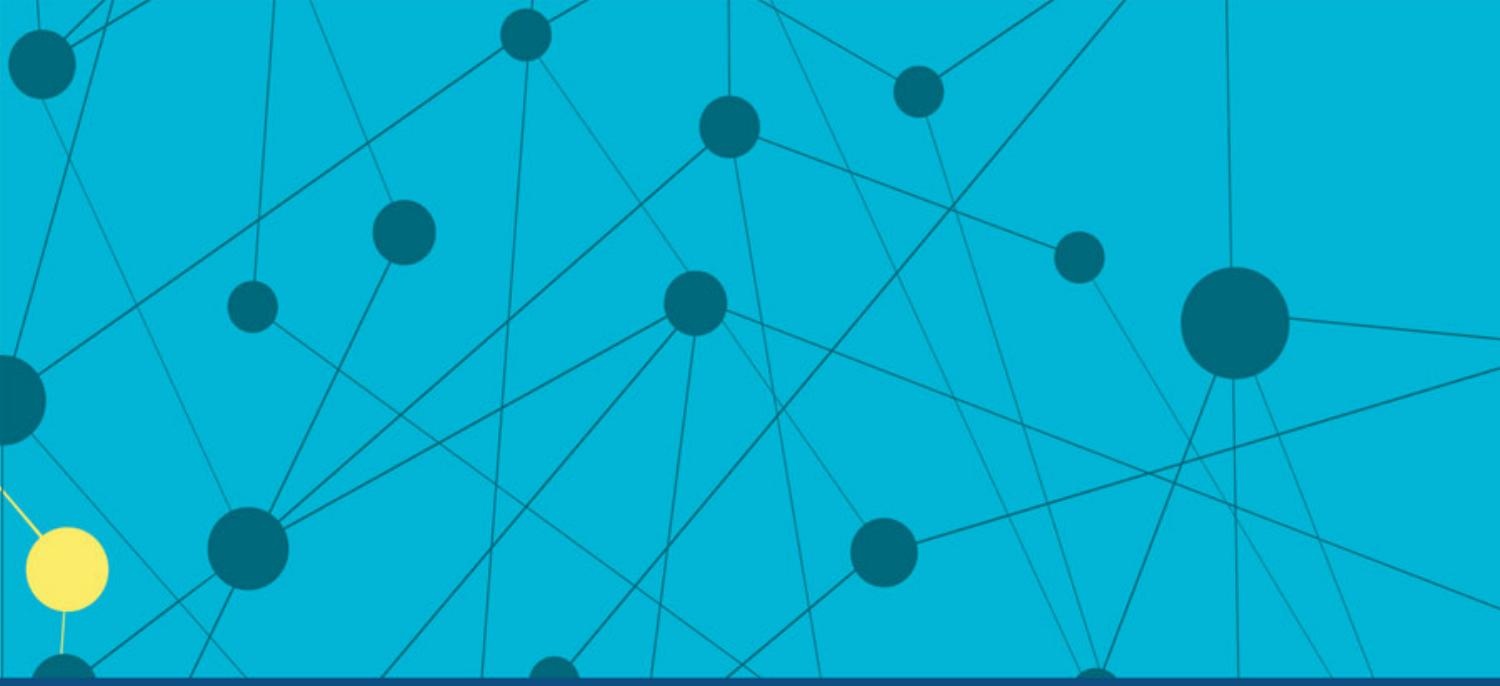

Routledge Studies in Language and Intercultural Communication

\title{
GLOCAL LANGUAGES AND CRITICAL INTERCULTURAL AWARENESS
}

\section{THE SOUTH ANSWERS BACK}

Edited by

Manuela Guilherme and Lynn Mario T. Menezes de Souza

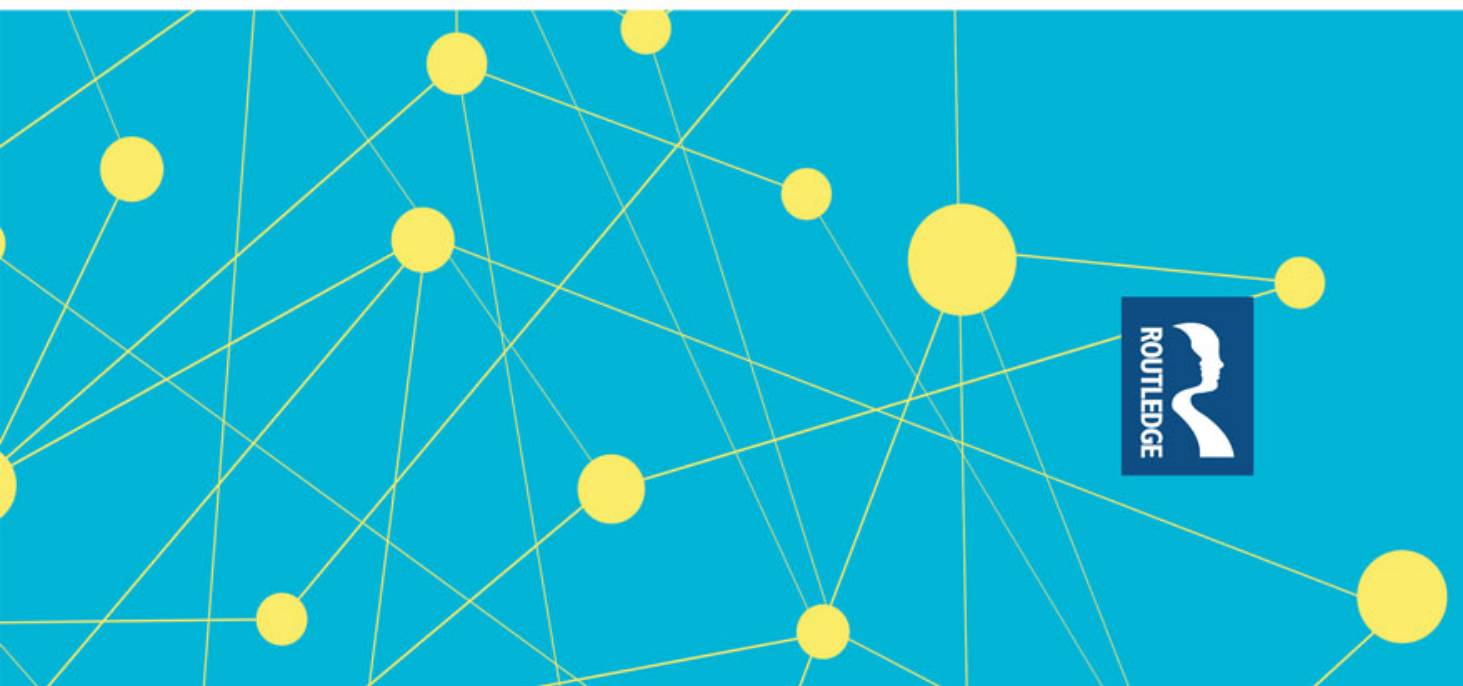




\section{Glocal Languages and Critical Intercultural Awareness}

This volume provides a new perspective on prevailing discourses on translanguaging and multilingualism by looking at 'glocal' languages, local languages which have been successfully 'globalised' and relocalised. Focusing on European languages recreated in Latin America, the book features examples from languages underexplored in the literature, namely Brazilian Portuguese, English and Spanish teaching in Brazilian universities, including Amerindian languages, as a basis for advocating for an approach to language education rooted in critical pedagogy and decolonial perspectives while countering hegemonic theories of globalisation. Being rooted in a discussion of the South, the book offers a fresh voice in current debates on language education that will be of broader interest to students and scholars across disciplines, including language education, multilingualism, cultural studies, and linguistic anthropology.

Manuela Guilherme is Senior Researcher at the Center for Social Studies at the University of Coimbra, Portugal, and was a Marie SklodowskaCurie Research Fellow (2014-2017).

Lynn Mario T. Menezes de Souza is Professor of Language Studies at the University of São Paulo, Brazil. 


\section{Routledge Studies in Language and Intercultural Communication}

Edited by

Zhu Hua,

Birkbeck College, University of London

Claire Kramsch,

University of California, Berkeley

Language and Intercultural Communication in the New Era

Edited by Farzad Sharifian and Maryam Jamarani

Reflexivity in Language and Intercultural Education

Rethinking Multilingualism and Interculturality

Edited by Julie S. Byrd Clark and Fred Dervin

Researching Identity and Interculturality

Edited by Fred Dervin and Karen Risager

Online Intercultural Exchange

Policy, Pedagogy, Practice

Edited by Robert O'Dowd and Tim Lewis

The Critical Turn in Language and Intercultural Communication

Pedagogy

Theory, Research and Practice

Edited by Maria Dasli and Adriana Raquel Diaz

Interculturality, Interaction and Language Learning

Insights from Tandem Partnerships

Jane Woodin

Beyond Native Speakerism

Current Explorations and Future Visions

Stephanie Ann Houghton, Damian J. Rivers and Kayoko Hashimoto

Screens and Scenes

Multimodal Communication in Online Intercultural Encounters

Edited Richard Kern and Christine Develotte

Glocal Languages and Critical Intercultural Awareness

The South Answers Back

Edited Manuela Guilherme and Lynn Mario T. Menezes de Souza

www.routledge.com/Routledge-Studies-in-Language-and-InterculturalCommunication/book-series/LICC 


\section{Glocal Languages and Critical Intercultural Awareness The South Answers Back}

Edited by Manuela Guilherme and Lynn Mario T. Menezes de Souza 
First published 2019

by Routledge

52 Vanderbilt Avenue, New York, NY 10017

and by Routledge

2 Park Square, Milton Park, Abingdon, Oxon OX14 4RN

Routledge is an imprint of the Taylor \& Francis Group, an informa business

(C) 2019 Taylor \& Francis

The right of the editors to be identified as the authors of the editorial material, and of the authors for their individual chapters, has been asserted in accordance with sections 77 and 78 of the Copyright, Designs and Patents Act 1988.

All rights reserved. No part of this book may be reprinted or reproduced or utilised in any form or by any electronic, mechanical, or other means, now known or hereafter invented, including photocopying and recording, or in any information storage or retrieval system, without permission in writing from the publishers.

Trademark notice: Product or corporate names may be trademarks or registered trademarks, and are used only for identification and explanation without intent to infringe.

Library of Congress Cataloging-in-Publication Data

A catalog record for this book has been requested

ISBN: 978-0-8153-9505-8 (hbk)

ISBN: 978-1-351-18465-6 (ebk)

Typeset in Sabon

by Apex CoVantage, LLC 


\section{Contents}

Introduction: Glocal Languages, the South Answering Back

\section{SECTION I}

Glocal Languages-Theoretical Background

1 Glocal Languages, Coloniality and Globalization From Below

LYNN MARIO T. MENEZES DE SOUZA

2 Glocal Languages Beyond Post-Colonialism: The Metaphorical North and South in the Geographical North and South MANUELA GUILHERME

\section{SECTION II}

Indigenous Languages as Glocal Languages

3 Glocalism Now and Then: The De-Colonial Turn of Guarani, Portuguese and Spanish FERNANDA MARTINS FELIX

4 Reshuffling Conceptual Cards: What Counts as Language in Lowland Indigenous South America 
vi Contents

SECTION III

Portuguese as Glocal Language

5 The Imaginary in Portuguese Language Perceptions in Academia: (Mis)directions Between the Local and the Global

GESUALDA DOS SANTOS RASIA

6 The Linguistic Atlas of Brazil Project: Contributions

Towards Knowledge, Teaching and Disclosure of

Brazilian Portuguese

MARCELA MOURA TORRES PAIM AND SILVANA SOARES COSTA RIBEIRO

\section{SECTION IV}

Spanish as Glocal Language

7 Comparisons Between Spanish and Portuguese:

Proposals for University Teaching

ADRIÁN PABLO FANJUL

8 Multiculturalism and Glocal Languages: The Impact of Cultural Mobility in Spanish Teaching and Learning in Southern Brazil

MARIA JOSELE BUCCO COELHO

\section{SECTION V}

English as Glocal Language

9 English (Mis)education as an Alternative to Challenge English Hegemony: A Geopolitical Debate

DANIEL DE MELLO FERRAZ

10 Teaching English to Undergraduate Students in a Brazilian University: Thinking Glocally

ALESSANDRA COUTINHO FERNANDES

Conclusion: Towards Globalization From Below

LYNN MARIO T. MENEZES DE SOUZA AND MANUELA GUILHERME

Contributors

Index 


\section{Acknowledgments}

This book owes much to the work carried out within the scope of the first phase (Oct. 2014-Oct. 2015) of the following project (Sept. 2014-Sept. 2017).

'Glocal Languages' and 'Intercultural Responsibility' in a postcolonial global academic world (GLOCADEMICS): Power relations between languages/cultures within and between research groups (www.ces. uc.pt/projectos/glocademics) funded by an individual grant awarded by the European Commission (Marie Sklodowska-Curie Actions) to Maria Manuela Duarte Guilherme, Principal Investigator and sole author of the proposal.

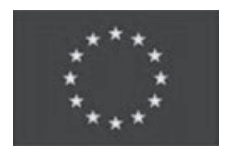

Project's home institution (2014-2017): Centro de Estudos Sociais, Universidade de Coimbra

General Coordinator of the Project: Boaventura de Sousa Santos

Project's home institution for the empirical study in Brazil: Departamento de Letras Modernas, Universidade de S. Paulo

Coordinator of the Project in Brazil: Lynn Mario T. Menezes de Souza

Therefore, the book editors are particularly grateful to the participants of Phase 1 of the project (2014-2015) who have accepted to author most of the chapters of this book and to make public some of their contributions to the project.

I, Manuela Guilherme, am deeply grateful for the efficient and valuable support, even at a distance, provided by the staff at the Centro de Estudos Sociais, Universidade de Coimbra, namely its Executive Director, João Paulo Dias, the Project Manager, André Caiado, the Coordinator of the Project Management Section (GAGEP), Rita Pais, the ICT Technician 


\section{viii Acknowledgments}

Pedro Abreu and the CES librarians, Maria José Carvalho, Acácio Machado and Inês Lima, as well as for their solidarity in times of personal distress. I am also very thankful to the other project participants who also contributed to Phase 1 of the project, most of whom are collaborating in other publications, as well as those colleagues who facilitated the implementation of the project in their departments and deserve my highest appreciation, namely Lynn Mario T. Menezes de Souza, Sávio Siqueira and Clarissa Jordão. I felt welcome, both personally and professionally, and intellectually stimulated by all the colleagues who hosted me in their various academic events at the Departmento de Línguas Modernas at the Universidade de S. Paulo, Instituto de Letras at the Universidade Federal da Bahia, and Departamento de Línguas Modernas and Centro de Línguas e Interculturalidade (CELIN), at the Universidade Federal do Paraná. Last but not the least, I am most grateful to Lynn Mario T. Menezes de Souza (USP) and Sávio Siqueira (UFBA) for having hosted me in their research groups and, therefore, also to their doctoral and postdoctoral students. 


\title{
Introduction
}

\section{Glocal Languages, the South Answering Back}

\author{
Manuela Guilherme and \\ Lynn Mario T. Menezes de Souza
}

This book aims to shed light on a particular perspective of the globalness and localness of some "glocal languages" (Portuguese, Spanish, English and Indigenous languages), having Brazil as its locus of enunciation and offering some highlights of language education in higher education there. The co-authors of this book are all involved in language education at the undergraduate level, and some also are in postgraduate programmesmost of them targeting teacher education-or have just completed their doctoral or post-doctoral research in any of the Brazilian universities participating in the "Glocademics" project, which was funded by a Marie Sklodowska-Curie fellowship, whose implementation in Brazil was coordinated by the book co-editors. The following texts emerge from within a study comprehending a small sample of language teaching (27 teachers of Portuguese, home and foreign language, Spanish and English as foreign or additional languages, and Indigenous languages, as additional languages) evenly distributed in three federal universities in Brazil. ${ }^{1}$ The study was based on curriculum analysis as well as direct written and oral statements by each participant teacher about their corresponding analysed syllabi and the theoretical background underlying their teaching activities and, finally, their conceptual frameworks. The following chapters aim to give public voice to the project participants who accepted this challenge. The numbers of language educators in the Brazilian higher education landscape are overwhelming; therefore, this book is far from aiming to provide a quantitatively representative view of the targeted field, but, by including the texts of scholars whose voice is acknowledged and highly respected by their colleagues, we hope to offer texts that qualitatively illustrate the thought and the practices of language education in the selected highly rated universities in Brazil.

Brazil covers an immense territory, almost half of South America. It became independent in the beginning of the 19th century, and two main moments when the Portuguese language was more fiercely imposed through nationwide linguistic policies can be singled out. First, in the late 18th century, by laws issued by the Marquês de Pombal, who was the authoritarian Secretary of State to the Portuguese King D. José I 


\section{Guilherme and Menezes de Sousa}

and who led the reconstruction of the city of Lisbon after the big 1775 earthquake as well as the political organisation of the territory. Second, during the 20th century, in the '30s and '40s, under the linguistic policies and the reinforcement of nationalism by Brazilian President Getúlio Vargas. Anyway, the Portuguese language had already become the language adopted by high society, to some extent also in rural areas, during the stay of the Portuguese Royal family and court in Brazil while fleeing from Bonaparte's invasion in the first half of the 18th century. The representation of the Portuguese language had also increased exponentially throughout the 18th century due to a substantial inflow of Portuguese colonisers (Lucchesi 2015). However, when European sailors and missionaries arrived at the coastal areas of Brazil they found more than a thousand Indigenous languages, most of which belonged to the largest tupi branch, whose tribes had been expelling other tribes with different cultural matrices for the past two centuries (Ribeiro 1995: 28). Several African languages arrived later through the arrest and forced importation of slaves. The situation during the 15 th and 16 th centuries was therefore one of heavy multilingualism, not only Indigenous but also European, such as Dutch in the north-eastern Recife area for example.

However, due to increased mobility and contact between the Indigenous populations and the immigrants, voluntary and involuntary, both from Europe and Africa, some "common languages" (lingua geral) started to become popular in the state of S. Paulo, later in the north-east and then travelled the rivers into Amazonia. These common languages, linguas gerais, were heavily based in specific stronger Indigenous languages, "tupi" and "tupinambá" "pidginised" with Portuguese and African languages, and later known as lingua geral paulista, lingua brasílica, língua geral amazónica and the latter also called Nheengatu in the 20th century (Ribeiro 1995; Freire 2014). Such common languages-lingua geralwere spread and registered by the colonisers (bandeirantes) and the Jesuit missionaries, the latter later expelled by the above mentioned Marquês de Pombal. Freire (2014) compares this process of creating common languages, in very wide regions, for religious, business, rural labour, social life, both in the private and public spheres, and still used for local government purposes, to the creation of "imagined communities" as proposed by Benedict Anderson. According to the same author, such "common languages" were widely used for "interethnic communication" in the states of São Paulo, Minas Gerais, Goiás, Mato Grosso and Pará and survived several prohibitions from the late 16th century to the late 19th century.

In the late 18th century, the predominance of the lingua geral also in large regions of inland on the Portuguese side in South America made difficult the separation between the lands owned by the Portuguese and the Spanish Crowns which were divided according to linguistic dominance (Freire 2014). However, it was due to this linguistic and cultural "plasticity" that the Portuguese colonisers, in too small numbers, managed to 
control the large territory of Brazil (Holanda 2016: 211-224). The 20th century was even more aggressive both towards Indigenous and immigrant languages (Italian, Dutch, Japanese, German, etc.), not only due to violently enforced linguistic policies for the use of Portuguese, both in the public and private spheres, but also due to the expansion of the education system. As a consequence, the Portuguese language definitely took the floor in almost half of South America. In the beginning of the 21st century, English and Spanish are also becoming important players in the economy and, therefore, in language education as well as in the internationalisation of education, the former pushed by globalisation and the latter by the Mercosul economic agreement (Asuncion Treaty Mercosur 1991).

This book undertakes a reverse South-North perspective; assuming that North and South are more than geographical positions, they are used as metaphors which express symbolic and conventional cultural and epistemological baggage present both in the geographical south and north. "North" and "South" are used not as ontological or geographical reference points but as epistemological sites involved in hegemonic relations of power both regionally and globally. Following this rationale, in terms of epistemological production, there are nowadays local souths within a global North and local norths within a global South. However, historically, this metaphor is inspired by the colonisation crusade that did move from North to South, that is, from Europe to wherever the sailors, missionaries and armies, altogether, could find their way, which happened to be southwards across the Atlantic Ocean. This book, and the Glocademics project from which it emerges, were inspired by Sousa Santos' theory on the Epistemologies of the South which is at the roots of what he calls the "ecology of knowledges" which demands an "intercultural translation" through which he argues that "it is imperative to start an intercultural dialogue among different critical knowledges and practices: South-centric and North-centric, popular and scientific, religious and secular, female and male, urban and rural, and so forth" (2014: 42). Promoting an ecology of knowledges does not, according to Sousa Santos, mean accepting relativism; on the contrary, it proposes "to reassess the concrete interventions in society and in nature that the different knowledges can offer" (205). Otherwise, it means that every knowledge, and every language, is incomplete, hence, in need to be reciprocally complemented.

Furthermore, the "Epistemologies of the South" does not propose the "South-North" divide as another dichotomy; instead it claims for a dialogue in equity among their pluralities. For example, Estermann (2008) explains that the Indigenous person cannot be defined in an essentialist manner, rather as part of a dialogical procedure, although violently imposed, between different philosophical models and not from the point of view of the dominant philosophical model only or 


\section{Guilherme and Menezes de Sousa}

otherwise ("No podemos, en fin, definir lo 'indígena' de manera essencialista sin caer con ello ya en una presuposición filosófica no articulada [la 'mania clasificatoria' del Occidente]. Lo 'indígena' tiene que surgir justamente como el resultado de un proceso dialógico entre diferentes modelos filosóficos, y no como un a priori de la filosofia dominante") (101). Sousa Santos (2007) elaborates on this divide, to be overcome, in terms of an "abyssal line" that has separated, on the one side of the line, scientific knowledge from, on the other side of the line, "beliefs, opinions, intuitive or subjective understandings, which, at the most, may become objects or raw materials for scientific inquiry" (47). Within such a conventionally imposed divide, if so understood, there is the adoption of scientific standards and academic criteria that meet cultural frameworks from the other side of the abyssal line, and which makes ratings of excellence more distant to the other side of the line. Post-abyssal times require that the south talks back, which "does not mean discarding the rich Eurocentric critical tradition" (Sousa Santos 2014: 44), instead that the South is also entitled to add their voices and that these are not only respected but that they also do count for a sustainable and ecological balance of knowledges. Such a position entails the negation of what CastroGómez (2005) calls the zero-point hubris-la bybris del punto cero-the knowledge that presumes to be the centre, before which nothing existed, universal and neutral, uncommitted, objective and unlimited unless by itself, therefore, that refuses any particular locus of enunciation, in sum, that observes without being observed.

Our approach to the term we are introducing and developing here"glocal languages"-is also inserted in what some authors call a decolonial turn ("El giro decolonial”) (Castro-Gómez and Grosfoguel 2007). This means not only leaving political colonialism behind, by moving into postcolonial governance, but also undoing the supremacy of the colonial epistemic heritage, by endorsing the creativeness of mestizage as equally legitimate, as well as by revitalising the remains of the colonial "epistemicide", the term used by Sousa Santos to name "the murder of knowledge" (2014: 92). According to Mignolo, a "de-colonial politics of knowledge" that entails a "knowledge-making for wellbeing rather than for controlling and managing populations for imperial interest shall come from local experiences and needs, rather from local imperial experiences and needs projected to the globe" (2009: 19). Elsewhere, Mignolo describes the decolonial thought as one that liberates and opens itself ("el pensamiento decolonial es, entonces, el pensamiento que se desprende y se abre") and explains that decoloniality of thought started occurring in simultaneity with epistemic colonisation throughout the history of colonisation (2007: 27). Moreover, Mignolo also states that the genealogy of decolonial thought is pluriversal, not universal ("la genealogia del pensamiento decolonial es pluriversal [not universal]") (ibid.: 45). 
Spivak (1999) in her Critique of Postcolonial Reason also concedes that "a certain postcolonial subject had, in turn, been recoding the colonial subject and appropriating the Native Informant's position" (1999: ix), meaning that postcolonial studies had not eventually made room for the colonised to re-appropriate the legitimacy of their identity, heritage and voice, in direct speech, but that the colonised is still being reported and analysed in scientific terms. The dialectical relation between coloniality and decoloniality, the ontological and epistemological nature of the colonial and decolonial beings, expresses itself well when referring to the "native/non-native" cultural and linguistic essence and status. The concept of "nativeness", no matter how mythical this concept is, is still today hierarchically dependent on the colonial matrices, e.g. the native Americans, the native languages, versus the native speaker of English, versus the native speaker of Portuguese or the native speaker of Spanish. We agree with Kumaravadivelu when he calls not only for "the unfreezing of the subaltern's potential for thinking otherwise" (2014: 79) but also for them to "activate [their] latent agentive capacity" (ibid.: 81). Therefore, Kumaravadivelu (2014) claims that "a grammar of decoloniality, if it is to be useful and useable, has to be formulated and implemented by local players" even though "they can, of course, be guided by a broader framework" (81) to which, we add, they should also have a say. And this also goes for languages which are viewed as global, like English, and whose localness is also "lost in translation". This is how we view global-localglocal-reciprocal dynamics, with mutual unlearning, learning and relearning. Language education cannot escape this challenge.

Our term "glocal languages" is inspired by the idea of "glocalization" put forward by Robertson to replace the terms "globalization" and "globality" which were, according to him, being loaded with notions with which he did not agree. Therefore, he adopted the term "glocalization", which already existed, in order to highlight some features of the globallocal nexus that had been neglected, and which we also find relevant, such as that "what is called local is in large degree constructed on a trans- or super-local basis" (1995: 26) and that "globality at this point being viewed in terms of the interpenetration of geographically distinct "civilizations" (ibid: 27). We are not, however, using the term "glocal" in order to clarify our understanding of the global dimension; instead, we believe that the impact of the "local" in the "global" is as strong as the reverse and, moreover, they are not in a dichotomous relationship but closely intertwining with each other.

According to Urry, the permanent interaction between the global and the local takes the form of a "complex relationality", as inspired by Marx and therefore between superstructure and agents, that "explains the ways in which local forms of information and action can result in the emergence of far-from-equilibrium system effects" (2005: 242). He adapts his analogy to globalisation by stating that "globalization 
(or global capitalism) is the new 'structure', while nations, localities, regions and so on, comprise the new 'agent'" (ibid.: 242) and we assume that one needs the other. Therefore, no matter the distance between the superstructure and the local agency, in globalisation, they are both very powerful, intense and tied together. However, capitalist globalisation viewed from the southern hemisphere seems even more invasive than from the perspective of the northern hemisphere because its language (English), its culture (technology and science) and its religion (secularism and atheism) have emanated from the North, so much that sometimes it is even forgotten by either side that, at this stage, it is colonising the geographical north as much as the south. Milton Santos (2000), a Brazilian geographer, calls it "globalitarianism" ("globalitarismo"), in order to connect it with authoritarianism.

Further inspiration for the adoption of this terminology comes from Sousa Santos' forms of production of globalisation, namely that of a "localised globalism", that the author describes as "the specific impact of transnational practices and imperatives on local conditions that are thereby destructured and restructured in order to respond to transnational imperatives" (1999: 217-218). However, our focus on "glocal languages" aims to go beyond the simple impact of the global on the local and it concentrates on the response of "localised globalisms" back to globalising practices and meanings. Sousa Santos' identification of the four forms of globalisation gives space for a "decolonial turn", since it acknowledges the localness of globalness by pinpointing that globalisation starts with: (a) "globalised localism", a localism that turned global but which, nevertheless, remains a localism, which homogeneous globalisation attempts to cover, and follows with the message that such "globalised localism" turns into a (b) "localised globalism", that is, it eventually lies in the hands, minds and hearts of local agents. Furthermore, the two remaining forms of production of globalisation identified by Sousa Santos (1999) also encompass two potential forms of agency for localness in the circumstances of globality: (c) cosmopolitanism and (d) common heritage of humankind, both of which invite individuals and collectives, namely social movements, to join and struggle across borders for common ideals, for the preservation of local natural and cultural wealth, for different forms of development, for epistemologies made invisible, for insurgent cosmopolitanism and for an ecology of knowledges, where languages are included.

The concept of "glocal languages", while moving beyond the "localised globalism", by undertaking a "decolonial" turn and by earning voice, therefore, implies claiming for the ownership and the revivification of colonial and colonised languages, that is, all of these implied in the different colonial matrices. The so-called Indigenous languages cease to be perceived as residuals of the past whose life and learning is circumscribed to the limits of their condition as endangered species to give 
way to general awareness of the linguistic, cultural epistemological and ontological value they have in providing us with different world visions (Cavalcanti and Maher 2017). The originally European languages must be regarded as they are in fact, having gained their autonomy and as standing on their own, of which Brazilian Portuguese is a good example. Considering them otherwise, still depending on their European roots and keeping them symbolically connected with colonialism, is a postcolonial perception of "glocalisations" whereas regarding them as linguae francae is putting them at the service of a neo-colonialist understanding of the globalisation of languages. Neither does keeping languages imprisoned in their past, at one end, nor throwing out that burden as if it had never existed, at the other end, offer a consistent solution.

The notion of "glocal languages" rests on an understanding of "multiscalar" criss-criss-crossing globalisations and localisations, in the plural, but nevertheless historically constituted, economically driven, hierarchically placed and in constant turbulence (Blommaert 2015; Canagarajah 2013; Mignolo 2000; Sousa Santos 2006, 2014). In agreement with Pietikäinen and Kelly-Holmes, who argue that "the peripheries are rarely examined in terms of their contribution to globalization; instead, they are often seen to follow rather than lead" (2013: 5), we have proposed the idea of "glocal languages" that avoid the "interest in global and local languages (echoing the centre-periphery distinction)" (ibid.: 6) and promote a critical dialogue and interplay between both on equity and reciprocity terms. Based on Bakhtin's (1981) tenets on the uninterrupted dynamics of heteroglossia, "glocal languages" profit from the centrifugal and centripetal forces of any living language, while taking meaning and shape at any moment in history in articulation with other moments of history and in simultaneity with other developments elsewhere.

The perception of the "glocal languages" conceptual framework as enunciated above, and in the following chapters, for the purpose of language education, inserts it within the scope of a decolonial intercultural approach to a critical pedagogy of language and culture. We propose a critical pedagogy in language education, following Paulo Freire's proposals, in that it addresses the political, social and cultural role of education and enhances the validation of the "glocal" critical and creative contribution of teachers and students to knowledge production (Guilherme 2002, 2012a, 2012b, 2015; Phipps and Guilherme 2004; Souza 2011). According to Torres, a connoisseur and a compagnon de route of Freire's work and life, Freire was also knowledgeable and influenced by the Critical Theory put forward by the Frankfurt School (Morrow and Torres 2002; Torres 2014). However, he made a "decolonial turn" and presented his own theory on Critical Pedagogy clearly rooted in the geographical and metaphorical Souths (Freire 1970, 1974, etc.) that continues to inspire critical pedagogues all over the world. 


\section{Guilherme and Menezes de Sousa}

In addition, the expression "critical intercultural awareness" put forward in the title of the book draws on Byram's proposal of "critical cultural awareness" proposed as an axiom, a fifth savoir-savoir s'engager, of his theory about Intercultural Communicative Competence $(1997,2008)$ that he later developed as a foundational tenet for citizenship education in language education, simultaneously with his work as a consultant for the Council of Europe. Guilherme (2002), following this line, expanded the theoretical grounds of this concept "critical cultural awareness" around Freire's works on Critical Pedagogy, also drawing on Frankfurt School's Critical Theory and Postmodernism. Byram and Guilherme's approaches differ, from the beginning, in that, Byram's approach to critical awareness in language and culture education may be characterised as pragmatist, of a Deweyan kind, while Guilherme's was inspired by the utopian work of Paulo Freire. Guilherme adopts Freire's sense of utopia, understood as the accomplishment of the "inédito viável" that she translates into the "[viable unknown] the 'not yet' that is still deemed feasible" (Guilherme 2017a: 431, 2017b, 2018). Not that Byram's and Guilherme's proposals ultimately separate in what concerns their perceptions of active democracy or intercultural dialogue, but that their conceptions of the cultural and the intercultural clearly emanate from different cultural matrices, and therefore intercultural matrices. Byram's focus emerges from the North, both the metaphorical and geographical one, and Guilherme's unfolds from the South, while both meet up in a situation of "intercultural translation" and "diatopical hermeneutics" as defined by Sousa Santos (2014), that is, in open positions that understand, respect and complement each other. The term "critical intercultural awareness" is adopted here, instead of "critical cultural awareness", precisely because this book intends to provide the readers with illustrations of a decolonial "intercultural translation" across and within language(s) and culture(s) rather than simply rely on the (post)colonial meeting of languages and cultures. Accordingly, we intend to respond to a particular cultural fabric of miscegenation that is evident in the Brazilian society and that responds to its specific colonial history. Our emphasis on a critical view of interculturality (a word that, in our work, only attempts to translate into English the term interculturalidad(e), both in Spanish and Portuguese) is also heavily grounded on the vast work by Walsh (2007, for example) throughout her long experience in Ecuador, about her concept "interculturalidad critica" which is endorsed by the editors of this book.

Finally, the chapters below, while dissecting the globalness and localness of Indigenous, Portuguese, Spanish and English languages, respond, in our view, to a critical and intercultural decolonial approach that is nowadays evident, both in the geographical and metaphorical South and North, in order to develop a "critical intercultural awareness" of language education that engages and commits teachers and students to issues of local, national and global citizenship. This book comprises a Section I 
entitled "'Glocal languages'-theoretical background" that aims to provide a theoretical background for the concept of "glocal languages" and within which we find Chapter 1 by Lynn Mario T. Menezes de Souza, entitled "Glocal Languages, Coloniality and Globalization From Below". This first chapter offers a critical analysis of the processes of globalisation and glocalisation as a background for the perception of the concept "glocal languages". The author undertakes a critical analysis of hegemonic and non-hegemonic globalisation and of the various theories supporting the conceptual framework for the notion of glocalisation. This chapter then contextualises the idea of "glocal languages" in relation to other theories that have been developed in order to examine language within the perspective of world communication nowadays. Finally, this chapter presents a perspective from the South on linguistic issues, with its locus of enunciation in Brazil. Chapter 2, by Manuela Guilherme, is entitled "Glocal Languages Beyond Post-Colonialism: The Metaphorical North and South in the Geographical North and South" and starts with an introductory reflection on the role of language in the constitution of nationality and in the imposition of coloniality. It then proceeds by describing the state of the art in the different perceptions of the linguistic landscape of today, through the analysis of other contemporary theories that contextualise, support or demand a different conceptual framework such as that of "glocal languages" that is developed in this book. This chapter clarifies the use of the North-South metaphor in relation to the geographical north and south and also critically addresses concepts of synchronicity and diachronicity. It discusses various aspects of multilingualism and conceptions of language and diversity as put forward by other authors. Finally, the author summarises the results of a study of language education (Portuguese, first and foreign language, English and Spanish as foreign or additional languages and Indigenous languages as additional languages) in three public universities in Brazil.

Section II addresses Indigenous languages as "glocal languages". It starts with Chapter 3 entitled "Glocalism Now and Then: The Decolonial Turn of Guarani, Portuguese and Spanish" by Fernanda Martins Felix. This chapter deals with an "Intercomprehension" project between Guarani, Portuguese and Spanish which is perceived as a response to the decolonial turn movement. The author provides us with the historical background of the three languages and offers theoretical support for the decolonial approach undertaken by this project carried out in collaboration with European partners within the scope of Galanet and MIRIADi projects. Finally, it discusses some of their activities. Section II also includes Chapter 4, by Jamille Pinheiro Dias, entitled "Reshuffling Conceptual Cards: What Counts as Language in Lowland Indigenous South America", that discusses communicative practices and potential notions of language in some Indigenous communities. Drawing mainly on applied linguistics and South American Indigenous ethnology, it calls 
for a broader ontological and epistemological understanding of what counts as "a language".

Section III deals with Portuguese as "glocal language" and includes Chapter 5 entitled "The Imaginary in Portuguese Language Perceptions in Academia: (Mis)directions between the Local and the Global" by Gesualda dos Santos Rasia that questions identity ties formed in a language that increasingly inhabits the interstices between the local and the global. Its theoretical background builds upon discourse studies with a materialistic approach by Pêcheaux put in relation to Bourdieu's theories in sociolinguistics which establish the ground for the analysis of the data collected through a study with some students of Brazilian Portuguese, both native and non-native. The title of Chapter 6 is "The Linguistic Atlas of Brazil Project: Contributions towards Knowledge, Teaching and Disclosure of Brazilian Portuguese" by Marcela Moura Torres Paim and Silvana Soares Costa Ribeiro. It describes the nationwide project ALIB - the Linguistic Atlas of Brazil that focuses on the immense variety of Brazilian Portuguese across its territories. It provides some examples of the data collected which give an impressive dimension of a "glocal language" within national borders.

Section IV includes two chapters on Spanish as "glocal language". It starts with Chapter 7, by Adrián Pablo Fanjul with the title "Comparisons between Spanish and Portuguese: Proposals for University Teaching" that deals with comparative research between South American Spanish and Brazilian Portuguese and its use in classroom activities. These courses have put together comparison topics which can be sorted into three main categories: the political delimitation of languages, discursivity and linguistic dynamics in its systemic aspects. Chapter 8, by Maria Josele Bucco Coelho, is entitled "Multiculturalism and Glocal Languages: The Impact of Cultural Mobility in Spanish Teaching and Learning in Southern Brazil" and deals with teaching of Spanish from the point of view of cultural mobility and multiculturalism. It aims to describe teaching strategies that better represent the plurality of cultural communities in Hispanic America by examining the curriculum proposal and teaching practices developed at the undergraduate level. The author considers this challenge as a local epistemic effort to let the experiences lived and suffered in Latin America shine through.

Section V deals with English as "glocal language" and begins with Chapter 9, by Daniel de Mello Ferraz, entitled "English (Mis)education as an Alternative to Challenge English Hegemony: A Geopolitical Debate". This chapter places critical perspectives on glob(c)alisation, (glocal) languages and language education in Brazil. It presents a brief state-of-the-art of globalisation and its connections to glocal relations and language education and discusses some perspectives regarding language education in Brazil through curricular analysis and, finally, through the voices of some pre-service teachers. Chapter 9, by Alessandra Coutinho 
Fernandes, with the title "Teaching English to Undergraduate Students in a Brazilian University: Thinking Glocally" undertakes an autobiographic and critical reflection upon the mythical "native speaker" of English and its role in Brazilian higher education, to follow with a critical analysis of the concept of globalisation as viewed from Brazil and its relation with the teaching and learning of English as it has been theorised by scholars from the geographical north and Brazilian ones as well. She finally adopts a "glocal" perspective and makes some proposals based on her own experience in English teaching at the Federal University of Paraná.

All the three public universities, among the largest in Brazil, participating in the Glocademics Marie Sklodowska-Curie project (Universidade de S. Paulo, Universidade Federal da Bahia and Universidade Federal do Paraná) are represented in this book. The Introduction and Conclusion, by the Editors, aim to contextualise, both politically and theoretically as well as experientially, the contents of this book and wrap up the messages found more relevant.

\section{Note}

1. Universidade de S. Paulo, Universidade Federal da Bahia and Universidade Federal do Paraná.

\section{References}

Asuncion Treaty Mercosur (1991) http://www.sice.oas.org/trade/mrcsr/mrcsrtoc. asp

Bakhtin, M. M. (1981) The Dialogic Imagination: Four Essays by M. M. Bakhtin. Edited by M. Holquist and Translated by C. Emerson and M. Holquist. Austin: University of Texas Press.

Blommaert, J. (2015) Chronotopes, scales and complexity: In the study of language in society. Annual Review of Anthropology, 44, 105-116.

Byram, M. (1997) Teaching and Assessing Intercultural Communicative Competence. Clevedon: Multilingual Matters.

Byram, M. (2008) From Foreign Language Education to Education for Intercultural Citizenship. Clevedon: Multilingual Matters.

Canagarajah, S. (2013) Agency and power in intercultural communication: Negotiating English in translocal spaces. Language and Intercultural Communication, 13, 2, 202-204.

Castro-Gómez, S. (2005) La Hybris del Punto Cero: Ciencia, raza e ilustración en la nueva granada (1750-1816). Bogotá: Pontificia Universidad Javeriana.

Castro-Gómez, S. and Grosfoguel, R. (eds.) (2007) El Giro Decolonial: Reflexiones para una diversidade epistémica más allá del capitalismo global. Bogotá: Siglo del Hombre Editores.

Cavalcanti, M. C. and Maher, T. M. (eds.) (2017) Multilingual Brazil: Language Resources, Identities and Ideologies in a Globalized World. New York: Routledge.

Estermann, J. (2008) Si el Sur fuera el Norte: Chakanas interculturales entre Andes y Occidente. La Paz: Instituto Superior ecuménico Andino de Teologia (ISEAT). 


\section{Guilherme and Menezes de Sousa}

Freire, J. R. B. (2014) A demarcação das línguas indígenas no Brasil. In M. C. Cunha and P. N. Cesarino (eds.) Politicas Culturais e Povos Indígenas (pp. 363-389). São Paulo: Editora UNESP.

Freire, P. (1970) Pedagogy of the Oppressed. New York: Continuum.

Freire, P. (1974) Education for Critical Consciousness. London: Sheed and Ward.

Guilherme, M. (2002) Critical Citizens for an Intercultural World: Foreign Language Education as Cultural Politics. Clevedon: Multilingual Matters.

Guilherme, M. (2012a) Critical language and intercultural communication pedagogy. In J. Jackson (ed.) The Routledge Handbook of Intercultural Communication (pp. 357-371). London: Routledge.

Guilherme, M. (2012b) Critical pedagogy. In C. A. Chapelle (ed.) The Encyclopaedia of Applied Linguistics. Oxford: Blackwell Publ.

Guilherme, M. (2015) Critical pedagogy. In J. M. Bennett (ed.) Encyclopaedia of Intercultural Competence (pp. 138-142). Thousand Oaks, CA: Sage.

Guilherme, M. (2017a) Freire's philosophical contribution for a theory of intercultural ethics: A deductive analysis of his work. Journal of Moral Education, 46, 4, 422-434.

Guilherme, M. (2017b) Visões de futuro em Freire e Dewey: Perspectivas interculturais das matrizes (pós)coloniais das Américas. ECCOS, 44, 205-223.

Guilherme, M. (2018) O diálogo intercultural entre Freire \& Dewey: O Sul e o Norte nas matrizes (pós)coloniais das Américas. Educação e Sociedade, 39, $142,89-105$.

Holanda, S. B. (2016) Raízes do Brasil. São Paulo: Companhia das Letras (1st ed., 1936).

Kumaravadivelu, B. (2014) The decolonial option in English teaching: Can the subaltern act? TESOL Quarterly, 50, 1, 66-85.

Lucchesi, D. (2015) Língua e Sociedade Partidas: A polarização sociolinguística do Brasil. São Paulo: Contexto.

Mignolo, W. D. (2000) Local Histories/Global Designs: Coloniality, Subaltern Knowledges, and Border Thinking. Princeton, NJ: Princeton University Press.

Mignolo, W. D. (2007) El pensamiento decolonial: Desprendimento y apertura (Un manifesto). In S. Castro-Gómez and R. Grosfoguel (eds.) El Giro Decolonial: Reflexiones para una diversidade epistémica más allá del capitalismo global (pp. 25-46). Bogotá: Siglo del Hombre Editores.

Mignolo, W. D. (2009) Epistemic disobedience, independent thought and decolonial freedom. Theory, Culture \& Society, 26, 7-8, 1-23.

Morrow, R. A. and Torres, C. A. (2002) Reading Freire and Habermas: Critical Pedagogy and Transformative Social Change. New York: Teachers College Press.

Phipps, A. and Guilherme, M. (eds.) (2004) Critical Pedagogy: Political Approaches to Language and Intercultural Communication. Clevedon: Multilingual Matters.

Pietikäinen, S. and Kelly-Holmes, H. (2013) Multilingualism and the periphery. In Multilingualism and the Periphery (pp. 1-16). Oxford: Oxford University Press.

Ribeiro, D. (1995) O Povo Brasileiro: A formação e o sentido do Brasil. São Paulo: Companhia de Bolso.

Robertson, R. (1995) Glocalization: Time-Space and Homogeneity-Heterogeneity. In M. Featherstone, S. Lash and R. Robertson (eds.) Global Modernities (pp. 25-44). London: Sage.

Santos, M. (2000) Por uma outra globalização: Do pensamento único à consciência universal. Rio de Janeiro: Editora Record (25th ed., 2015). 
Sousa Santos, B. (1999) Towards a multicultural conception of human rights. In M. Featherstone (ed.) Spaces of Culture: City, Nation, World (pp. 214229). London: Sage.

Sousa Santos, B. (2006) Globalizations. Theory, Culture \& Society, 23, 2-3, 393-399.

Sousa Santos, B. (2007) Beyond abyssal thinking: From global lines to ecologies of knowledges. Review, 30, 1, 45-89.

Sousa Santos, B. (2014) The Epistemologies of the South. Boulder: Paradigm.

Souza, L. M. (2011) Para uma Redefinição de Letramento Crítico. In R. F. Maciel and V. A. Araújo (eds.) Formação de Professores de Linguas: Ampliando perspectivas (pp. 128-140). Jundiaí, São Paulo: Paco Editorial.

Spivak, G. C. (1999) A Critique of Postcolonial Reason. Cambridge, MA: Harvard University Press.

Torres, C. A. (2014) First Freire: Early Writings in Social Justice Education. New York: Teachers College.

Urry, J. (2005) The complexities of the global. Theory, Culture \& Society, 22, 5, 235-254.

Walsh, C. (2007) Shifting the geopolitics of critical knowledge. Cultural Studies, 21, 2-3, 224-239. 